\title{
PENGEMBANGAN TRANSFERABLE SKILLS DALAM PEMBELAJARAN PRODUKTIF SEKOLAH MENENGAH KEJURUAN DI ERA INDUSTRI 4.0
}

\author{
Yulianto Eko Wibowo ${ }^{1}$, Rodia Syamwil ${ }^{2}$ \\ ${ }^{1}$ Jurusan Pendidikan Teknik Mesin, Universitas Negeri Yogyakarta, \\ ${ }^{2}$ Jurusan Pendidikan Tata Busana, Universitas Negeri Semarang \\ Email: yulianto.eko@uny.ac.id)
}

\begin{abstract}
The demand of industries in the fulfillment of labor is more complex because it must be suitable to the competencies in hard skills and soft skills. The Vocational High School (SMK) becomes pivotal in fulfilling the needs of industrial labor. The transferable skills to be developed are communication, cooperation, discipline and responsibility. The purpose of this study is to analyze those transferable skills in learning process of a productive course at vocational high school and how much have the students absorb those soft skills. This research is a descriptive research using mixed method approach. The results show the soft skills in productivecourse learning in numbers: communication ability $87.18 \%$ (very good criteria), cooperation $86.14 \%$ (very good criteria), discipline $89.64 \%$ (very good criteria), and responsibility $86.78 \%$ (very good criteria). Whereas for the absorption of the soft skills: communication $83.37 \%$ (good criteria), cooperation $86.16 \%$ (very good criteria), disclipine $80.43 \%$ (good criteria) and responsibility $82.07 \%$ (good criteria). The implementation of transferable skills in productive-course learning in SMK has succeded and is in accordance to the objectives and demands of the Industrial Revolution 4.0. This can be reinforced by accustomization of character and behavior of the students so that they always communicate actively, be cooperative, have discipline and show responsibility in learning process.
\end{abstract}

Keywords: soft skills, productive learning

\begin{abstract}
ABSTRAK
Tuntutan industri dalam pemenuhan tenaga kerja era Industri 4.0 bernilai lebih kompleks karena harus disesuaikan dengan kompetensi hard skills maupun soft skills. SMK menjadi point penting dalam pemenuhan kebutuhan tenaga kerja industri. Transferable skills yang dikembangkan adalah komunikasi, kerjasama, dan kedisiplinan dan tanggung jawab. Tujuannya adalah untuk menganalisis pengembangan transferable skills dalam pembelajaran produktif di SMK dan keterserapan soft skills siswa SMK. Penelitian ini merupakan penelitian deskriptif pendekatan mix methods. Transferable skills dalam pembelajaran produktif SMK menghasilkan pengembangan soft skill kemampuan berkomunikasi mencapai $87.18 \%$ kriteria sangat baik, soft skill kerjasama mencapai $86.14 \%$ kriteria sangat baik, soft skill disiplin $89.64 \%$ kriteria sangat baik dan soft skill tanggung jawab 86.78\% kriteria sangat baik. Keterserapan soft skill kemampuan berkomunikasi mencapai 83.37\% kriteria baik, soft skill kerjasama mencapai $86.16 \%$ kriteria sangat baik, soft skill disiplin mencapai 80.43\% kriteria baik, dan soft skill tanggung jawab 82.07 kriteria baik. Transferable skills dalam pembelajaran produktif SMK di Kota Semarang sudah dilaksanakan dengan baik sesuai tujuan dan tuntutan era Industri 4.0. Hal ini perlu dikuatkan dengan pembiasaan sifat dan sikap siswa untuk selalu aktif berkomunikasi, bekerjasama, disiplin dan bertanggung jawab dalam proses pembelajaran.
\end{abstract}

Kata kunci: Soft Skills, Pembelajaran Produktif

\section{PENDAHULUAN}

BPS merilis data tahun 2019 mengenai Tingkat Pengangguran Terbuka (TPT) dilihat dari tingkat pendidikan keseluruhan penduduk Indonesia, yang hasilnya adalah lulusan SMK berada di urutan pertama dengan capaian
8,63\%; kemudian dilanjutkan dengan lulusan Diploma I/II/III dengan capaian $6,89 \%$; lulusan SMA dengan capaian $6,78 \%$; lulusan Universitas dengan capaian $6,24 \%$; lulusan SMP dengan capaian 5,04\%; dan terakhir adalah lulusan SD ke bawah dengan capaian $2,65 \%$. Data di atas menunjukkan bahwa lulusan SMK masih menjadi donatur nomor 
satu dengan penyumbang persentase terbanyak pengangguran di Indonesia dibandingkan dengan lulusan dari lembaga pendidikan lainnya. Hal ini juga menjadi sorotan bahwa pendidikan di SMK masih mempunyai PR yang begitu banyak, salah satunya dengan memperbaiki permasalahan yang sangkut pautnya dengan lulusan.

Data BPS di atas, ternyata sejalan dengan beberapa kejadian di lapangan. Lulusan SMK seharusnya mampu untuk langsung mendapatkan pekerjaan sesuai dengan kompetensi yang dibutuhkan oleh industri, namun kenyataan dilapangan masih menunjukkan bahwa kompetensi yang dimiliki lulusan SMK belum sejalan dengan kondisi industri sekarang. Ketidaksesuaian antara perkembangan ilmu pengetahuan dan teknologi yang digunakan oleh sekolah dengan teknologi yang digunakan oleh dunia industri menyebabkan ilmu yang dipelajari siswa SMK tidak sinkron dengan tuntutan industri sekarang. Permasalahan perbedaan ilmu pengetahuan dan teknologi di atas bukan menjadi permasalahan utama, melainkan ada permasalahan lain yaitu masalah kompetensi yang dimiliki siswa sebagai calon tenaga kerja. Dunia industri era 4.0 menuntut tenaga kerja untuk bisa menghasilkan produk yang berkualitas dengan melalui kinerja yang baik. Kompetensi yang dibutuhkan oleh tenaga kerja sudah diatur oleh pemerintah melalui Kementerian Tenaga Kerja dan Transmigrasi Republik Indonesia. Standar kompetensi ini merupakan hal yang bersifat mendasar mengenai apa saja yang wajib dan mampu dilakukan oleh tenaga kerja di industri, meliputi aspek keterampilan, pengetahuan dan perilaku yang disesuaikan dengan dunia industri.

Dunia industri membutuhkan sumber daya manusia yang berkualitas guna menghasilkan produk berkualitas dan mampu bersaing, ini yang menyebabkan industri selektif dalam penerimaan pekerja agar sesuai dengan kompetensi yaitu tenaga kerja yang kompeten dalam aspek hard skills dan aspek soft skills.
...What competencies are believed to be most important for the 21 century? I adopt OECD's usage, in its Definition and Selection of Competencies (DeSeCo) Project, of 'competency.' A competency is ...more than just knowledge and skills. It involves the ability to meet complex demands, by drawing on and mobilizing psychosocial resources (including skills and attitudes) in a particular context. For example, the ability to communicate effectively is a competency that may draw on an individual's knowledge of language, practical IT skills and attitudes towards those with whom he or she is communicating" (OECD, 2005:4).

Pernyataan di atas menjelaskan bahwa kompetensi yang terpenting bagi tenaga kerja pada abad 21 ini adalah bukan hanya sekedar mempunyai pengetahuan dan teknik keterampilan saja, melainkan harus diimbangi dengan kemampuan soft skills.

Kemampuan soft skill mempunyai nilai penting dalam perkembangan dunia industri, apalagi di era industri 4.0 seperti sekarang ini. soft skill menjadi salah satu point penting untuk bisa diterima dalam dunia kerja. Hal ini menjadikan siswa lulusan SMK secara tidak langsung harus mampu menguasai aspek soft skill dikarenakan tuntutan kerja dan tantangan kerja di dunia industri sekarang.

Kemampuan soft skills yang dibutuhkan pada era revolusi industri 4.0 seperti sekarang ini antara lain kemampuan berbahasa / berkomunikasi, kemampuan attitude atau kemampuan bersikap pekerja saat bekerja di industri, tanggung jawab, dispilin kejujuran, loyalitas, kerja sama serta kesopanan dan intregitas, pemahaman kualitas produk nomor satu, berpenampilan sopan, ketekunan.

Soft skills yang dijabarkan di atas, sejalan dengan penjelasan dari Kimbrell dan Vineyard (2006:57) yang mengungkapkan mengenai soft skills didunia industri antara lain 1) inisiatif; 2) etika / integritas; 3) berfikir kritis; 4) kemauan untuk belajar; 5) mempunyai komitmen tinggi; 6) mempunyai motivasi tinggi, 7) bersemangat; 8) dapat diandalkan; 9) kemampuan 
berkomunikasi; 10) kreatif; 11) kemampuan menganalisi; 12) dapat mengatasi stress; 13) manajemen diri; 14) kemampuan menyelesaikan permasalahan; 15) dapat meringkas; 16) berkolerasi / kolaborasi; 17) fleksibel; 18) mampu bekerjasama dalam tim; 19) mandiri; 20) kemampuan mendengarkan; 21) tangguh; 22) berargumentasi secara logis, dan 23) mampu manejemen waktu.

Temuan lain dilapangan yang menjadi permasalahan adalah kemampuan teknik hard skills pekerja banyak yang tidak tertunjang kemampuan soft skills memadai. Hal ini ternyata sesuai dengan keadaan di pendidikan di Indonesia khususnya di SMK yang cenderung berorientasi pada pendidikan hard skills saja, namun kurang pada pengembangan kemampuan soft skills (Ali, 2011:13).

Permasalahan - permasalahan yang dihadapi SMK di atas, menunjukkan bahwa terjadi ketidaklinearan antara kenyataan di lapangan dengan tujuan pendidikan SMK. UU SISDIKNAS nomor 20 tahun 2003 menyebutkan "pendidikan kejuruan merupakan pendidikan yang mempersiapkan siswa untuk dapat bekerja dalam bidang tertentu". Hal ini serupa dengan Permendiknas No. 23 tahun 2006 Menteri Pendidikan Nasional bahwa profil lulusan SMK adalah menguasai kompetensi program keahlian dan kewirausahaan baik untuk memenuhi tuntutan dunia kerja maupun mengikuti pendidikan tinggi sesuai dengan kejuruannya.

Uraian di atas juga sejalan dengan hasil penelitian Surya (2013:7) yang membuat kesimpulan bahwa bahwa pendidikan kejuruan merupakan pendidikan menengah yang mempersiapkan siswa untuk menjadi tenaga kerja dan mandiri dalam bidang tertentu dan SMK diharapkan mampu menghasilkan lulusan yang berkualitas dan berkompeten sesuai dengan kebutuhan dunia industri untuk selalu bersaing.

Pemerintah dalam Inpres No 6 Tahun 2014 tentang Peningkatan Daya Saing Nasional menjabarkan peningkatan daya saing tenaga kerja dan peningkatan kompetensi serta produktivitas tenaga kerja, maka masyarakat Indonesia diharapkan mampu untuk mempunyai hard skills dan soft skills yang kompeten sehingga mampu untuk bersaing dengan masyarakat lainnya.

Peranan pendidikan kejuruan khususnya SMK mempunyai nilai strategis dalam mempersiapkan calon tenaga kerja yang memiliki keterampilan profesional tertentu untuk memperoleh bidang pekerjaan yang sesuai dengan spesialisasi, selain itu dapat berwirausaha dan melanjutkan pendidikan hingga ke perguruan tinggi. Hal ini menggambarkan bahwa dunia pendidikan kejuruan khususnya SMK seharusnya mempunyai pengelolaan yang baik bagi siswanya agar bisa mendapatkan kompetensi yang bisa menjadi modal bersaing dan sesuai dengan kebutuhan industri era 4.0.

Hal ini sesuai Permendikbud nomor 65 Tahun 2013 tentang Standar Proses Pendidikan Dasar dan Menengah mengenai prinsip pembelajaran yaitu harus terjadi peningkatan dan keseimbangan antara keterampilan fisikal (hard skills) dan keterampilan mental (soft skills) bagi siswa.

Peranan aspek soft skills mempunyai posisi penting dalam pendidikan di SMK karena di dalamnya banyak terkandung aspek karakter kerja yang diperlukan sebagai pelengkap kompetensi yang harus dikuasai oleh siswa, namun dari aspek inilah muncul permasalahan baru yaitu guru belum menampakan secara optimal dalam proses pembelajaran mengenai pelaksanaan soft skills seperti menumbuhkan rasa tanggung jawab dan disiplin, mulai dari persiapan diri, persiapan kerja, proses produksi, dan berkemas. Guru lebih memusatkan perhatian pada pengembangan kemampuan untuk penguasaan ilmu pengetahuan dan teknologi sehingga semakin berkurangnya perhatian terhadap pembelajaran soft skills yang berdampak pada rendahnya soft skills bagi lulusan (Tim Pakar Yayasan Jati Diri Bangsa, 2011).

Pendidikan kejuruan khususnya SMK mampu menempatkan porsi lebih banyak dalam 
pembelajaran produktif guna mengasah kemampuan hard skills siswa agar sesuai dengan kebutuhan industri. Pembelajaran produktif selain mengajarkan siswa untuk memperoleh kompetensi keahlian hard skills, seharusnya mampu mengajarkan soft skills sebagai pendamping kompetensi yang diajarkan karena soft skills menjadi aspek penting seseorang dalam bekerja.

Pembelajaran soft skills akan membentuk siswa menjadi tenaga kerja dengan kualitas kompetensi yang baik dan sesuai dengan kebutuhan industri untuk menghadapi persaingan. Membentuk siswa SMK menjadi human capital dengan pembelajaran soft skills yang baik memang bukanlah hal yang mudah, maka membutuhkan proses pembelajaran yang menunjang baik secara adaptif, normatif dan produktif.

Pembelajaran produktif di dalam kelas maupun di dalam workshop akan merangsang peningkatan hard skills dan soft skills dari siswa. Hard skills diwujudkan dalam bentuk kompetensi siswa dalam proses keterampilan skills sesuai keahlian, sedangkan soft skills siswa diwujudkan dalam bentuk keterampilan dan kecakapan dalam mengelola diri agar lebih berkembang dan berkompeten.

Pengembangan pembelajaran soft skills diharapkan mampu untuk menggambarkan skills siswa selama menjalani proses pembelajaran. Perkembangan siswa yang berkualitas secara hard skills dan soft skills dapat dihasilkan dari kolaboratif antara proses pembelajaran produktif, kemampuan guru dalam proses pembelajaran dan lembaga pendidikan serta industri melalui pembelajaran soft skills bagi siswa.

\section{METODE}

Penelitian ini dilakukan di Sekolah Menengah Kejuruan (SMK) berstatus Negeri di Kota Semarang dengan jumlah populasi 6 sekolah. SMK yang menjadi sampel ditentukan dengan menggunakan teknik Probability Sampling dimana pengambilan sampel yang memberikan peluang yang sama bagi setiap unsur (anggota) populasi untuk dipilih menjadi anggota sampel. Sampel dalam penelitian ini diambil secara Simple Random Sampling yang merupakan pengambilan anggota sampel dari populasi yang dilakukan secara acak tanpa memperhatikan strata yang ada dalam populasi tersebut (Sugiyono, 2014:82). Teknis pengambilan sampel SMK dipilih secara acak dengan cara membuat gulungan dari kertas yang berisikan nama SMK yang termasuk dalam populasi, kemudian diambil gulungan sejumlah 3 gulungan dari total keseluruhan 6 gulungan, kemudian 3 gulungan terpilih menjadi sampel dari penelitian.

Teknik pengumpulan data yang digunakan adalah teknik kuesioner / angket, teknik observasi / pengamatan dan teknik dokumentasi. Instrumen yang digunakan dalam penelitian ini digunakan untuk menggali data dari kuesioner Transferable Skills oleh guru dan keterserapan soft skills siswa. Data yang diperoleh pada penelitian ini adalah data kuantitatif. Instrumen yang digunakan yaitu kuesioner Transferable Skills dan keterserapan soft skills siswa serta lembar observasi. Analisis deskriptif disajikan dengan bentuk tabel, diagram dan persentase.

Penelitian ini menggunakan uji validitas instrumen dan uji realibilitas. Uji validitas butir instrument (1) Transferable Skills dalam pembelajaran produktif menghasilkan butir soal yang valid sebanyak 64 butir dan yang tidak valid sebanyak 6 butir dengan nilai realibilitas (Crombach's Alpha) sebesar 0.976 keterserapan soft skills siswa menghasilkan butir soal yang valid sebanyak 60 butir dan yang tidak valid sebanyak 10 butir nilai realibilitas (Crombach's Alpha) sebesar 0.946.

Analisa yang digunakan adalah analisis deskriptif. Transferable Skills dalam pembelajaran produktif akan dihitung dengan menggunakan hasil kuesioner yang kemudian diperkuat dengan hasil observasi kualitatif dan selanjutnya akan diselaraskan dengan hasil keterserapan soft skills bagi siswa. 


\section{HASIL DAN PEMBAHASAN}

Hasil penelitian di SMK Negeri "A" kota Semarang selengkapnya disampaikan dalam Tabel 1 dan Gambar 1-6.

Tabel 1. Nilai Hasil Kuesioner Transferable Skills di SMK Negeri "A" Kota Semarang

\begin{tabular}{lccc}
\hline \multicolumn{1}{c}{$\begin{array}{c}\text { Aspek Soft } \\
\quad \text { Rkills }\end{array}$} & Rerata & $\%$ & Rerata \% \\
\hline Berkomunikasi & 4,16 & $83,17 \%$ & \\
Kerjasama & 4,12 & $82,42 \%$ & \\
Disiplin & 4,26 & $85,21 \%$ & $83,50 \%$ \\
Tanggung & 4,16 & $83,22 \%$ & \\
Jawab & & & \\
\hline
\end{tabular}

Berdasarkan hasil Tabel 1, kemudian dibuat diagram persentase dengan hasil seperti dalam Gambar 1.

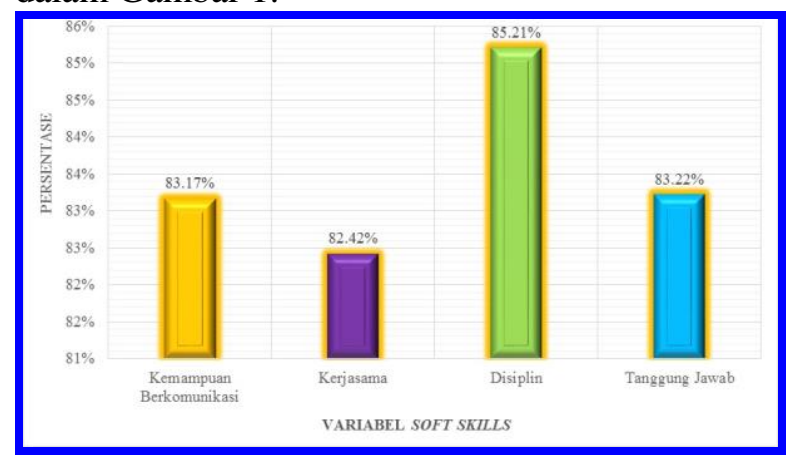

Gambar 1. Persentase Transferable Skills dalam Pembelajaran Produktif SMK Negeri "A" Kota Semarang

Hasil perhitungan distribusi frekuensi relatif masing-masing kriteria dari transferable skills dalam Pembelajaran Produktif SMK Negeri "A" kota Semarang disampaikan dalam Tabel 2.

Tabel 2. Distribusi Frekuensi Nilai Transferable Skills dalam Pembelajaran Produktif SMK Negeri "A” Kota Semarang

\begin{tabular}{crrc}
\hline Persentase & F & \multicolumn{1}{c}{ FR } & Kriteria \\
\hline $82.2 \%-100 \%$ & 14 & $100 \%$ & Sangat Baik \\
$66.7 \%-81.1 \%$ & 0 & $0 \%$ & Baik \\
$51.1 \%-65.6 \%$ & 0 & $0 \%$ & Kurang Baik \\
$35.6 \%-50 \%$ & 0 & $0 \%$ & Tidak Baik \\
$20 \%-34.4 \%$ & 0 & $0 \%$ & $\begin{array}{c}\text { Sangat Tidak } \\
\text { Baik }\end{array}$ \\
\hline \multicolumn{4}{c}{ Jumlah } \\
\hline
\end{tabular}

Berdasarkan data hasil penelitian di SMK Negeri " $A$ " yang diperoleh, maka persentase transferable skill untuk soft skill kemampuan berkomunikasi $83.17 \%$ kriteria sangat baik, soft skill kerjasama $82.42 \%$ kriteria sangat baik, soft skill disiplin $85.21 \%$ kriteria sangat baik, dan soft skill tanggung jawab $83.22 \%$ kriteria sangat baik.

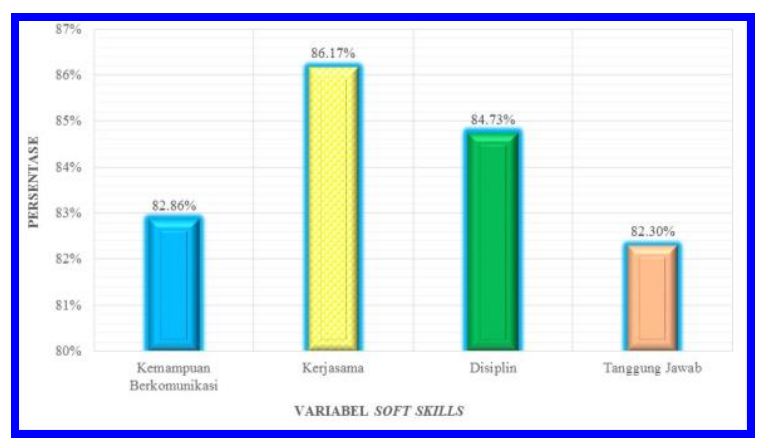

Gambar 2. Persentase Keterserapan Soft Skills Siswa SMK Negeri “A” Kota Semarang

Berdasarkan Gambar 2, maka persentase keterserapan soft skill untuk soft skill kemampuan berkomunikasi siswa mencapai $82,86 \%$ termasuk kriteria baik, soft skill kerjasama siswa mencapai $86.17 \%$ termasuk kriteria sangat baik, soft skill disiplin siswa mencapai $84.73 \%$ termasuk kriteria sangat baik, dan soft skill tanggung jawab siswa mencapai $82.30 \%$ termasuk kriteria baik.

Penjabaran dari masing - masing soft skill disampaikan melalui Gambar 3-6. Kemampuan berkomunikasi disampaikan dalam Gambar 3.

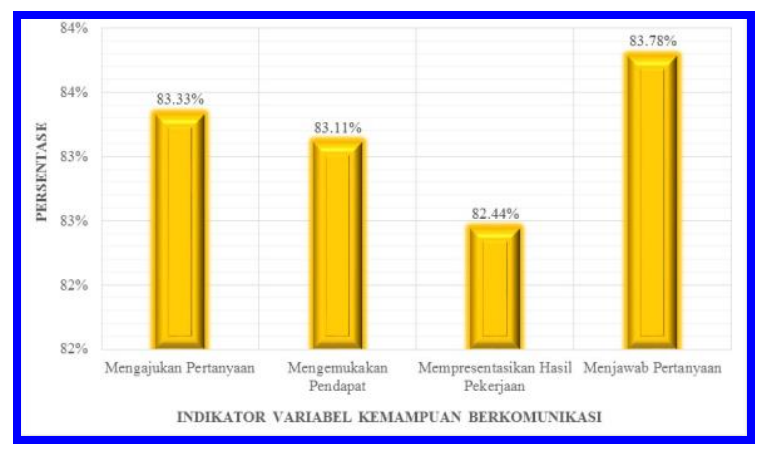

Gambar 3. Persentase Transferable Skill Kemampuan Berkomunikasi dalam Pembelajaran Produktif SMK Negeri "A" Kota Semarang 
Berdasarkan Gambar 3, maka persentase transferable skills untuk soft skill berkomunikasi dalam hal (1) memberikan kesempatan siswa untuk mengajukan pertanyaan mencapai $83.33 \%$ (sangat baik); (2) membantu siswa untuk mengemukakan pendapat mencapai $83.11 \%$ (sangat baik); (3) membantu siswa mempresentasikan hasil pekerjaan mencapai $82.44 \%$ (sangat baik); dan (4) memberi kesempatan kepada siswa menjawab pertanyaan mencapai $83.78 \%$ (sangat baik).

Kemampuan kerjasama disampaikan selengkapnya dalam Gambar 4.

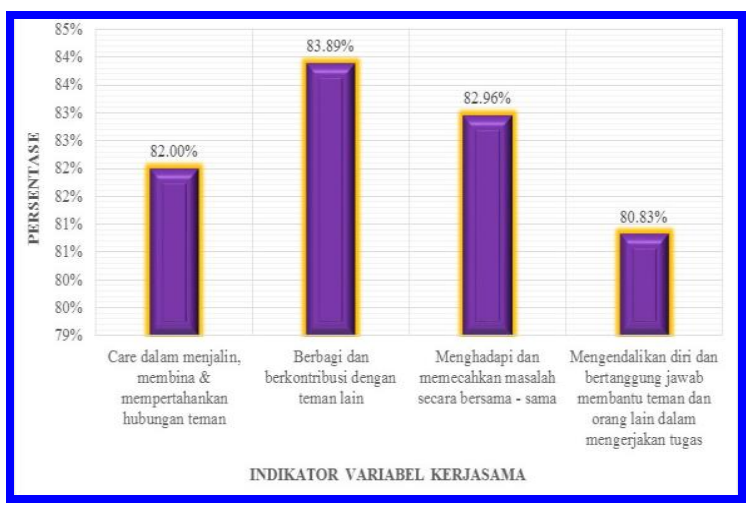

Gambar 4. Persentase Transferable Skill

Kerjasama dalam Pembelajaran Produktif SMK Negeri "A" Kota Semarang

Berdasarkan Gambar 4, maka persentase transferable skills untuk soft skill kerjasama dalam hal (1) mengajarkan untuk care dalam menjalin, membina dan mempertahankan hubungan teman mencapai $82.00 \%$ (sangat baik); (2) mengajarkan untuk berbagi dan berkontribusi dengan teman lain mencapai $83.89 \%$ (sangat baik); (3) mengajarkan dalam menghadapi dan memecahkan masalah secara bersama mencapai $82.96 \%$ (sangat baik); dan (4) mengajarkan pengendalian diri, tanggung jawab membantu teman dan orang lain dalam mengerjakan tugas mencapai $80.83 \%$ (sangat baik).

Selanjutnya, aspek kedisiplinan disampaikan dalam Gambar 5.

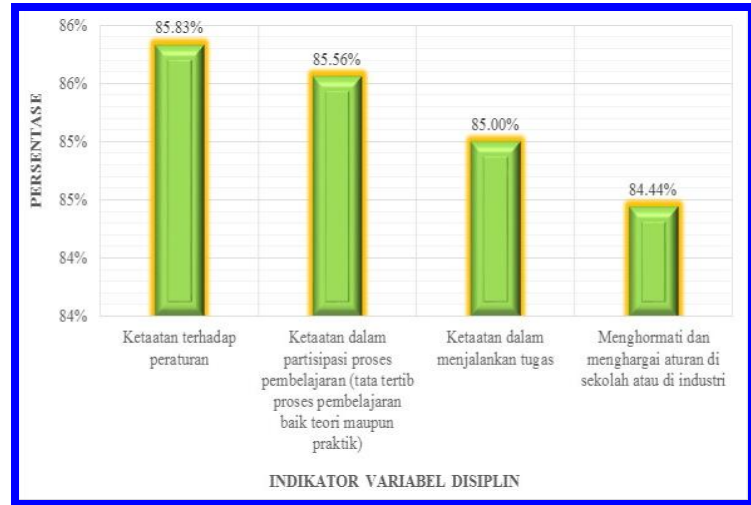

Gambar 5. Persentase Transferable Skill Disiplin dalam Pembelajaran Produktif SMK Negeri "A" Kota Semarang

Berdasarkan Gambar 5, maka persentase transferable skills untuk soft skill disiplin dalam hal (1) guru mengajarkan siswa taat terhadap peraturan mencapai $85.83 \%$ (sangat baik); (2) guru mengajarkan siswa taat dalam partisipasi proses pembelajaran mencapai $85.56 \%$ (sangat baik); (3) guru mengajarkan siswa taat dalam menjalankan tugas mencapai $85.00 \%$ (sangat baik); dan (4) guru mengajarkan siswa menghormati dan menghargai aturan di sekolah atau di industri mencapai $84.44 \%$ (sangat baik).

$\begin{array}{ccr}\text { Pada } \quad \text { aspek } & \text { kemampuan } \\ \text { tanggungjawab, } & \text { hasil } & \text { penelitian } \\ \text { disampaikan dalam Gambar } 6 . & \end{array}$

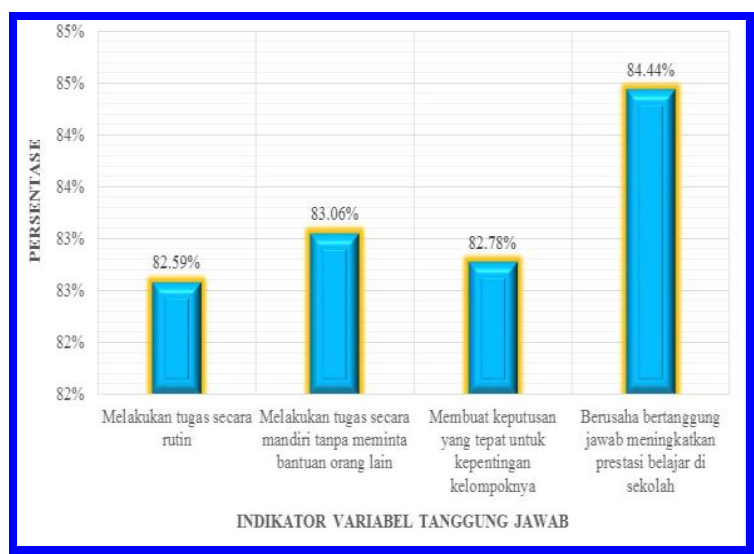

Gambar 6. Persentase Transferable Skill Tanggung Jawab dalam Pembelajaran Produktif SMK Negeri "A" Kota Semarang 
Berdasarkan Gambar 6, maka persentase transferable skills untuk soft skill tanggung jawab dalam hal (1) memberikan tugas rutin mencapai $82.59 \%$ (sangat baik); (2) mengajarkan siswa untuk melakukan tugas secara mandiri mencapai $83.06 \%$ (sangat baik); (3) mengajarkan siswa untuk membuat keputusan yang tepat untuk kepentingan kelompoknya mencapai $82.78 \%$ (sangat baik); dan (4) mengajarkan siswa untuk berusaha bertanggung jawab meningkatkan prestasi di sekolah mencapai $84.44 \%$ (sangat baik).

Hasil penelitian di SMK Negeri "B" kota Semarang selengkapnya disampaikan dalam Tabel 3-4 dan Gambar 7-12.

Tabel 3. Nilai Hasil Kuesioner Transferable Skills di SMK Negeri "B" Kota Semarang

\begin{tabular}{lccc}
\hline \multicolumn{1}{c}{$\begin{array}{c}\text { Aspek Soft } \\
\quad \text { Skills }\end{array}$} & Rerata & $\%$ & Rerata \% \\
\hline Berkomunikasi & 4,04 & $80,83 \%$ & \\
Kerjasama & 3,90 & $78,10 \%$ & \\
Disiplin & 4,42 & $88,46 \%$ & $82,08 \%$ \\
Tanggung & 4,05 & $80,94 \%$ & \\
Jawab & & & \\
\hline
\end{tabular}

Berdasarkan hasil Tabel 3, kemudian di buat diagram persentase dengan hasil seperti pada Gambar 7.

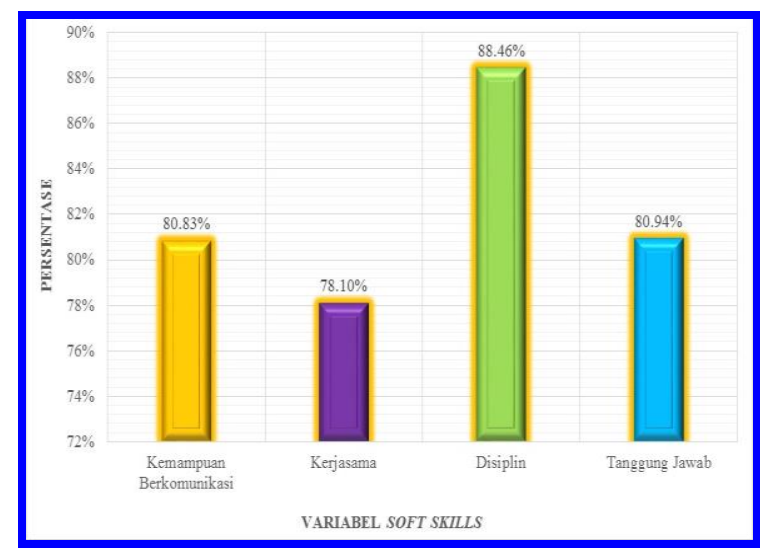

Gambar 7. Persentase Transferable Skills dalam Pembelajaran Produktif SMK Negeri "B" Kota Semarang

Hasil perhitungan distribusi frekuensi relatif masing-masing kriteria dari transferable skills dalam Pembelajaran Produktif SMK
Negeri "B" Kota Semarang disampaikan dalam Tabel 4.

Tabel 4. Distribusi Frekuensi Nilai Transferable Skills dalam Pembelajaran Produktif SMK Negeri "B" Kota Semarang

\begin{tabular}{ccrc}
\hline Persentase & F & \multicolumn{1}{c}{ FR } & Kriteria \\
\hline $86.7 \%-100 \%$ & 1 & $20 \%$ & Sangat Baik \\
$70 \%-83.3 \%$ & 4 & $80 \%$ & Baik \\
$53.3 \%-66.7 \%$ & 0 & $0 \%$ & Kurang Baik \\
$36.7 \%-50 \%$ & 0 & $0 \%$ & Tidak Baik \\
$20 \%-33.3 \%$ & 0 & $0 \%$ & $\begin{array}{c}\text { Sangat Tidak } \\
\text { Baik }\end{array}$ \\
\hline Jumlah & 5 & $100 \%$ & \\
\hline
\end{tabular}

Rerata \% Transferable Skills adalah $82.08 \%$ dengan kategori Baik

$\mathrm{F}=$ Frekuensi; FR = Frekuensi Relatif

Berdasarkan data hasil penelitian di SMK Negeri "B" yang diperoleh, maka persentase transferable skill untuk soft skill kemampuan berkomunikasi mencapai 80,83 \% termasuk kriteria baik, soft skill kerjasama mencapai $78.10 \%$ termasuk kriteria baik, soft skill disiplin mencapai $88.46 \%$ termasuk kriteria sangat baik, dan soft skill tanggung jawab mencapai $80.94 \%$ termasuk kriteria baik.

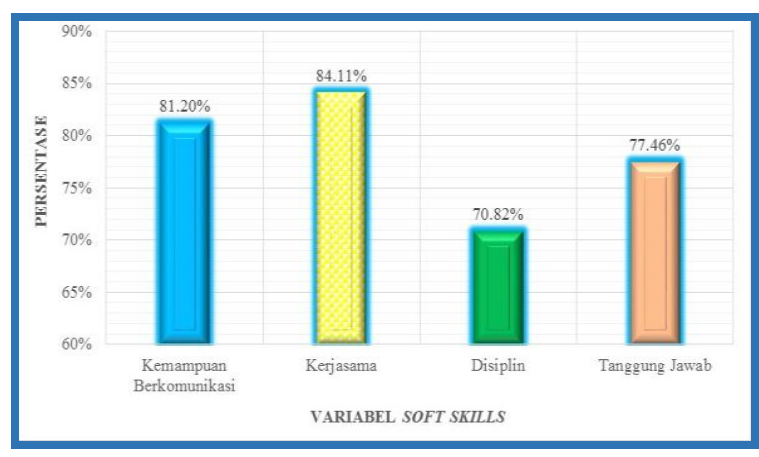

Gambar 8. Persentase Keterserapan Soft Skills Siswa SMK Negeri "B" Kota Semarang

Berdasarkan Gambar 8, maka persentase keterserapan soft skill untuk soft skill kemampuan berkomunikasi peserta didik mencapai $81.20 \%$ termasuk kriteria baik, soft skill kerjasama peserta didik mencapai $84.11 \%$ termasuk kriteria baik, soft skill disiplin peserta didik mencapai $70.82 \%$ termasuk kriteria baik, dan soft skill tanggung jawab peserta didik mencapai $77.46 \%$ termasuk kriteria baik. 
Penjabaran dari masing-masing soft skill disampaikan dalam Gambar 9-12. Gambar 9 menyampaikan data mengenai kemampuan berkomunikasi.

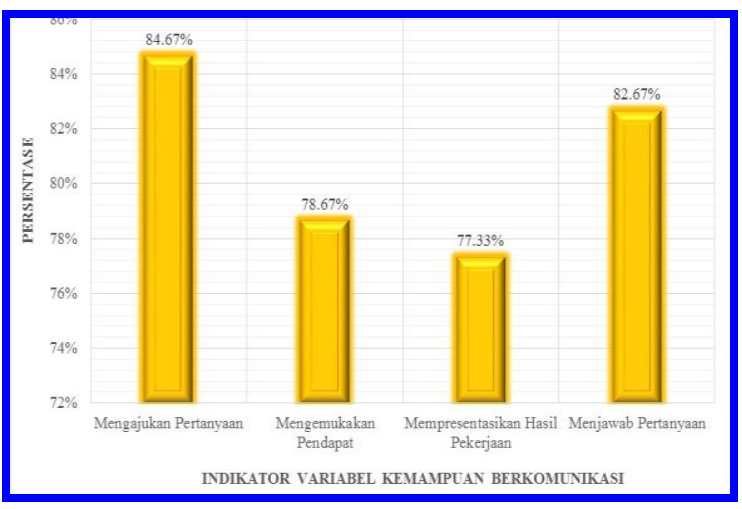

Gambar 9. Persentase Transferable Skill

Kemampuan Berkomunikasi dalam Pembelajaran Produktif SMK Negeri "B" Kota Semarang

Berdasarkan Gambar 9, maka persentase transferable skill untuk soft skill berkomunikasi dalam hal (1) memberikan kesempatan siswa mengajukan pertanyaan mencapai $84.67 \%$ (baik); (2) membantu siswa mengemukakan pendapat mencapai $78.67 \%$ (baik); membantu siswa mempresentasikan hasil pekerjaan mencapai $77.33 \%$ (baik); dan (4) memberi kesempatan kepada siswa menjawab pertanyaan mencapai $82.67 \%$ (baik).

Selanjutnya, kemampuan kerjasama disampaikan dalam Gambar 10.

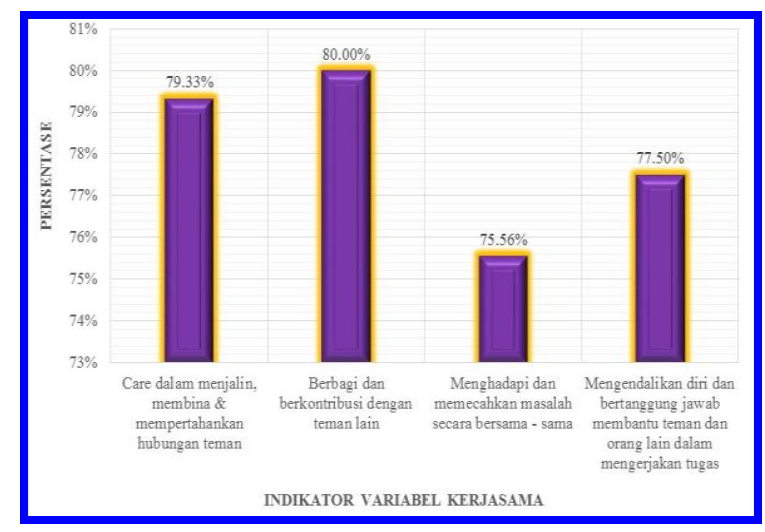

Gambar 10. Persentase Transferable Skill Kerjasama dalam Pembelajaran Produktif SMK Negeri "B" Kota Semarang
Berdasarkan Gambar 10, maka persentase transferable skill untuk soft skill kerjasama dalam hal (1) mengajarkan care dalam menjalin, membina dan mempertahankan hubungan teman mencapai $79.33 \%$ (baik); (2) mengajarkan berbagi dan berkontribusi dengan teman lain mencapai $80.00 \%$ (baik); (3) mengajarkan menghadapi dan memecahkan masalah secara bersama - sama mencapai $75.56 \%$ (baik); dan (4) mengajarkan pengendalian diri serta tanggung jawab membantu teman dan orang lain dalam mengerjakan tugas mencapai $77.50 \%$ (baik).

Kemampuan dalam hal disiplin, disampaikan dalam Gambar 11.

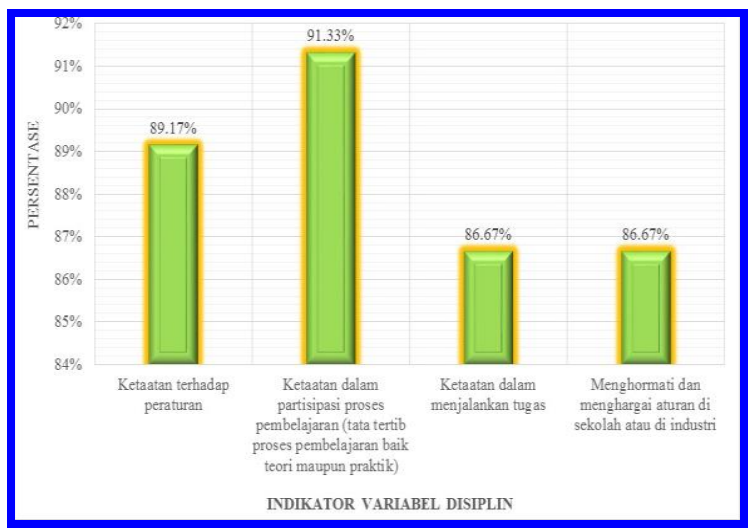

Gambar 11. Persentase Transferable Skill Disiplin dalam Pembelajaran Produktif SMK Negeri "B" Kota Semarang

Berdasarkan Gambar 11, maka persentase transferable skill untuk soft skill disiplin dalam hal (1) mengajarkan taat terhadap peraturan mencapai $89.17 \%$ (sangat baik); (2) mengajarkan taat dalam partisipasi proses pembelajaran mencapai 91.33\% (sangat baik); (3) mengajarkan taat dalam menjalankan tugas mencapai $86.67 \%$ (baik); dan (4) mengajarkan menghormati dan menghargai aturan di sekolah atau di industri mencapai $86.67 \%$ (baik).

Kemudian untuk kemampuan tanggungjawab, hasil penelitian disampaikan dalam Gambar 12. 


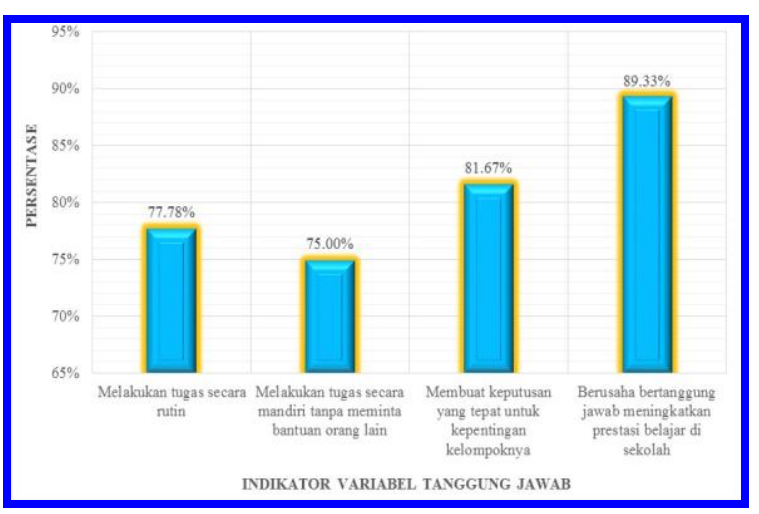

Gambar 12. Persentase Transferable Skills

Tanggung Jawab dalam Pembelajaran Produktif SMK Negeri "B" Kota Semarang

Berdasarkan Gambar 12, maka persentase transferable skill untuk soft skill tanggung jawab dalam hal (1) memberikan tugas rutin mencapai $77.78 \%$ (baik); (2) mengajarkan melakukan tugas secara mandiri mencapai $75.00 \%$ (baik); (3) mengajarkan membuat keputusan yang tepat untuk kepentingan kelompoknya mencapai $81.67 \%$ (baik); dan (4) mengajarkan bertanggung jawab meningkatkan prestasi di sekolah mencapai $89.33 \%$ (sangat baik).

Hasil penelitian di SMK Negeri "C" Kota Semarang disampaikan dalam Tabel 5-6 dan Gmbar 13-18.

Tabel 5. Nilai Hasil Kuesioner Transferable Skills di SMK Negeri 7 Semarang

\begin{tabular}{lccc}
\hline \multicolumn{1}{c}{ Aspek Soft } & Rerata & $\%$ & Rerata \% \\
\hline Berkomunikasi & 4,46 & $89,30 \%$ & \\
Kerjasama & 4,44 & $88,75 \%$ & \\
Disiplin & 4,49 & $89,86 \%$ & $88,88 \%$ \\
Tanggung & 4,38 & $87,61 \%$ & \\
Jawab & & & \\
\hline
\end{tabular}

Berdasarkan hasil Tabel 5, kemudian dibuat diagram persentase dengan hasil seperti dalam Gambar 13.

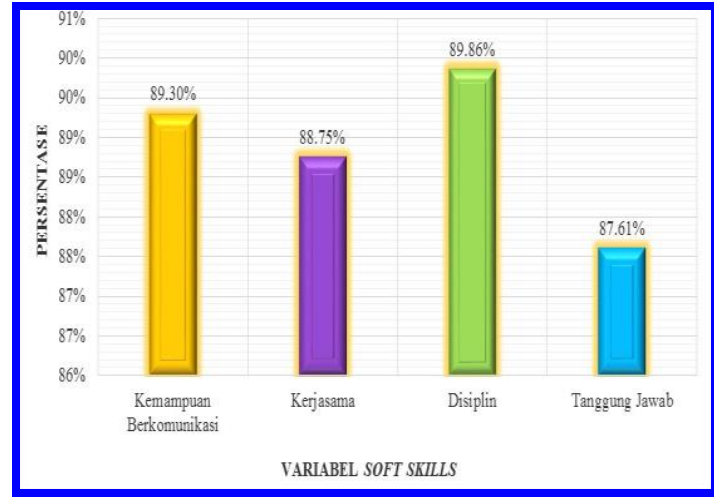

Gambar 13. Persentase Transferable Skills dalam Pembelajaran Produktif SMK Negeri

"C" Kota Semarang

Tabel 6. Distribusi Frekuensi Nilai Transferable Skills dalam Pembelajaran Produktif SMK Negeri "C" Kota Semarang

\begin{tabular}{|c|c|c|c|}
\hline Persentase & $\mathrm{F}$ & FR & Kriteria \\
\hline $84 \%-100 \%$ & 6 & $75 \%$ & Sangat Baik \\
\hline $68 \%-83 \%$ & 2 & $25 \%$ & Baik \\
\hline $52 \%-67 \%$ & 0 & $0 \%$ & $\begin{array}{c}\text { Kurang } \\
\text { Baik }\end{array}$ \\
\hline $36 \%-51 \%$ & 0 & $0 \%$ & Tidak Baik \\
\hline $20 \%-35 \%$ & 0 & $0 \%$ & $\begin{array}{c}\text { Sangat } \\
\text { Tidak Baik }\end{array}$ \\
\hline Jumlah & 8 & \multicolumn{2}{|l|}{$100 \%$} \\
\hline $\begin{array}{l}\text { Rerata \% Tran } \\
\text { dengan kategori }\end{array}$ & & Skills a & h $88.88 \%$ \\
\hline
\end{tabular}

Berdasarkan data hasil penelitian di SMK Negeri "C" yang diperoleh, maka persentase transferable skill untuk soft skill berkomunikasi mencapai $89.30 \%$ termasuk kriteria sangat baik, soft skill kerjasama mencapai $88.75 \%$ termasuk kriteria sangat baik, soft skill disiplin mencapai $89.86 \%$ termasuk kriteria sangat baik, dan soft skill tanggung jawab mencapai $87.61 \%$ termasuk kriteria sangat baik.

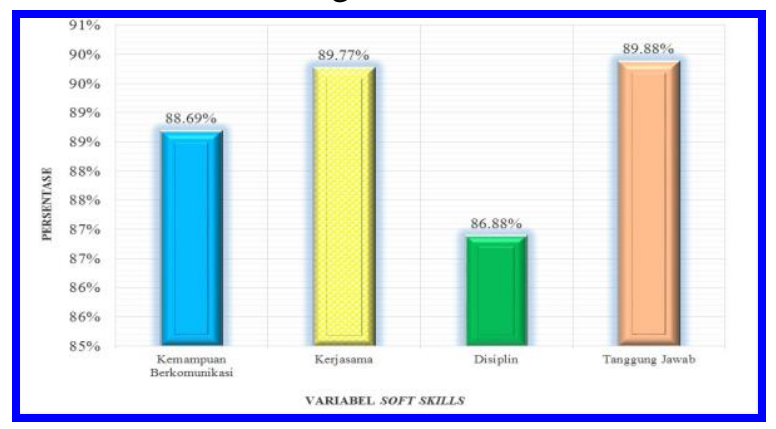

Gambar 14. Persentase Keterserapan Soft Skills Siswa SMK Negeri "C" Kota Semarang 
Berdasarkan Gambar 14, maka persentase keterserapan soft skill untuk soft skill kemampuan berkomunikasi peserta didik mencapai $88.69 \%$ termasuk kriteria sangat baik, soft skill kerjasama peserta didik mencapai $89.77 \%$ termasuk kriteria sangat baik, soft skill disiplin peserta didik mencapai $86.88 \%$ termasuk kriteria sangat baik, dan soft skill tanggung jawab peserta didik mencapai $89.88 \%$ termasuk kriteria sangat baik.

Penjabaran dari masing - masing soft skills disampaikan melalui penjelasan dan Gambar 15-18. Kemampuan berkomunikasi disampaikan dalam Gambar 15.

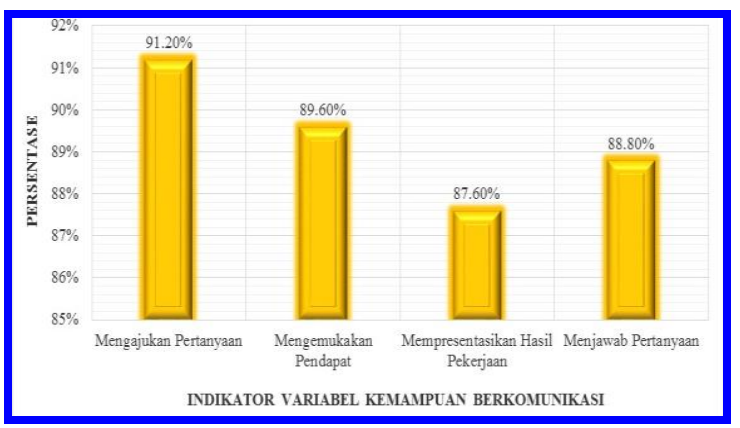

Gambar 15. Persentase Transferable Skills

Kemampuan Berkomunikasi dalam Pembelajaran Produktif SMK Negeri "C" Kota Semarang

Berdasarkan Gambar 15, maka persentase transferable skills untuk soft skill kemampuan berkomunikasi dalam hal (1) memberikan kesempatan untuk mengajukan pertanyaan mencapai $91.20 \%$ (sangat baik); (2) membantu siswa mengemukakan pendapat mencapai $89.60 \%$ (sangat baik); (3) membantu siswa mempresentasikan hasil pekerjaan mencapai $87.60 \%$ (sangat baik); dan (4) memberi kesempatan kepada siswa menjawab pertanyaan mencapai $88.80 \%$ (sangat baik).

Hasil penelitian mengenai Kemampuan Kerjasama disampaikan dalam Gambar 16.

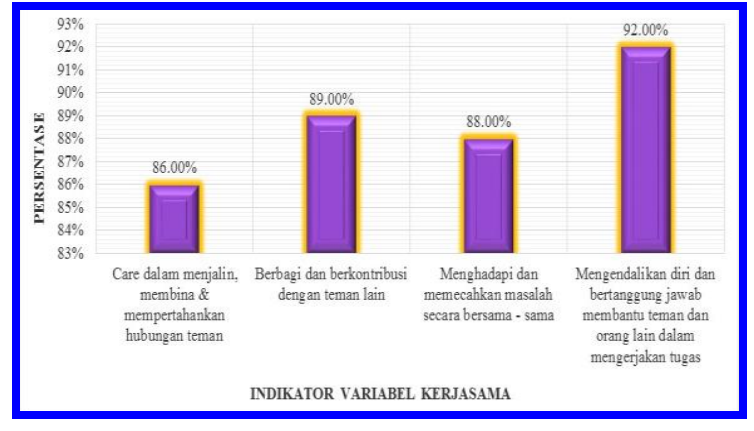

Gambar 16. Persentase Transferable Skills Kerjasama dalam Pembelajaran Produktif SMK Negeri "C" Kota Semarang

Berdasarkan diagram di atas, maka persentase transferable skills untuk soft skill kerjasama dalam hal (1) mengajarkan care dalam menjalin, membina dan mempertahankan hubungan teman mencapai $86.00 \%$ (sangat baik); (2) mengajarkan berbagi dan berkontribusi dengan teman lain mencapai $89.00 \%$ (sangat baik); (3) mengajarkan untuk menghadapi dan memecahkan masalah secara bersama - sama mencapai $88.00 \%$ (sangat baik); dan (4) mengajarkan pengendalian diri serta tanggung jawab membantu teman dan orang lain dalam mengerjakan tugas mencapai $92.00 \%$ (sangat baik).

Kemampuan disiplin disampaikan dalam Gambar 17.

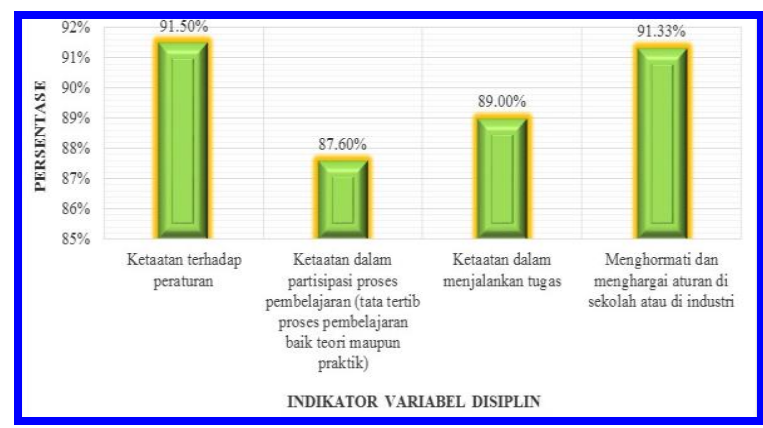

Gambar 17. Persentase Transferable Skills Disiplin dalam Pembelajaran Produktif SMK Negeri "C" Kota Semarang

Berdasarkan Gambar 17, maka persentase transferable skills untuk soft skill disiplin dalam hal (1) mengajarkan taat terhadap peraturan mencapai $91.50 \%$ (sangat baik); (2) mengajarkan taat dalam partisipasi proses pembelajaran mencapai $87.60 \%$ (sangat 
baik); (3) mengajarkan taat dalam menjalankan tugas mencapai $89.00 \%$ (sangat baik); dan (4) mengajarkan untuk menghormati dan menghargai aturan di sekolah atau di industri mencapai $91.33 \%$ (sangat baik).

Penjabaran mengenai kemampuan tanggungjawab disampaikan dalam Gambar 18.

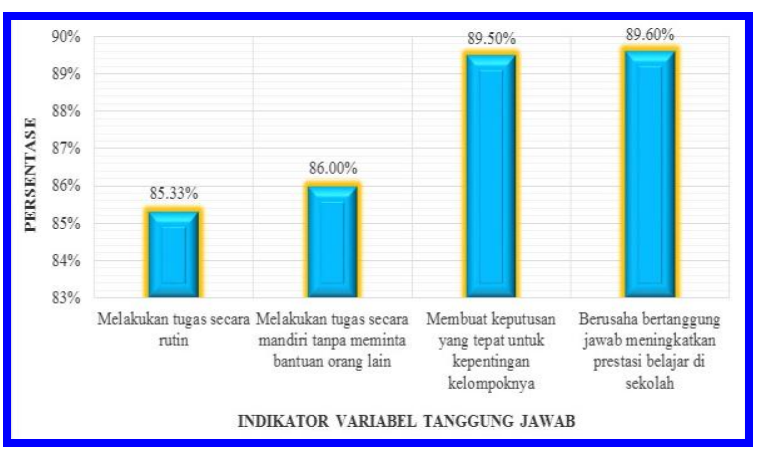

Gambar 18. Persentase Transferable Skills Tanggung Jawab dalam Pembelajaran Produktif SMK Negeri "C" Kota Semarang

Berdasarkan Gambar 18, maka persentase transferable skills untuk soft skill tanggung jawab dalam hal (1) memberikan tugas rutin kepada siswa mencapai $85.33 \%$ (sangat baik); (2) mengajarkan untuk melakukan tugas secara mandiri mencapai $86.00 \%$ (sangat baik); (3) mengajarkan membuat keputusan yang tepat untuk kepentingan kelompoknya mencapai $89.50 \%$ (sangat baik); dan (4) mengajarkan bertanggung jawab meningkatkan prestasi di sekolah mencapai $89.60 \%$ (sangat baik).

\section{SIMPULAN}

Berdasarkan hasil penelitian dan pembahasan, maka dapat ditarik kesimpulan sebagai berikut. (1) Transferable skills dalam pembelajaran produktif SMK di Kota Semarang mengikuti era industri 4.0 sudah dilakukan dengan baik, hal ini bisa dilihat dari hasil persentase transferable skills dalam pembelajaran produktif untuk SMK Negeri "A" Kota Semarang, SMK Negeri "B" Kota Semarang dan SMK Negeri "C" Kota Semarang. Hasilnya adalah persentase transferable skills SMK
Negeri "A" Kota Semarang untuk soft skill kemampuan berkomunikasi mencapai $83.17 \%$ kriteria sangat baik; soft skill kerjasama mencapai $82.42 \%$ kriteria baik; soft skill disiplin mencapai $85.21 \%$ kriteria sangat baik; dan soft skill tanggung jawab sebesar $83.22 \%$ kriteria sangat baik. Persentase transferable skills SMK Negeri "B" Kota Semarang untuk soft skill kemampuan berkomunikasi mencapai $80.83 \%$ kriteria baik; soft skill kerjasama mencapai $78.10 \%$ kriteria baik; soft skill disiplin mencapai $88.46 \%$ kriteria sangat baik; dan soft skill tanggung jawab sebesar $80.94 \%$ kriteria baik. Persentase transferable skills SMK Negeri "C" Kota Semarang untuk soft skill kemampuan berkomunikasi mencapai $89.30 \%$ kriteria sangat baik; soft skill kerjasama mencapai $88.75 \%$ kriteria sangat baik; soft skill disiplin mencapai $89.86 \%$ kriteria sangat baik; dan soft skill tanggung jawab sebesar $87.61 \%$ kriteria sangat baik. (2) Transferable skills dalam pembelajaran produktif SMK di Kota Semarang mengikuti era industri 4.0 sudah dilakukan dengan baik, hal ini bisa dilihat dari hasil persentase transferable skills secara generalisasi dalam pembelajaran produktif untuk soft skills kemampuan berkomunikasi mencapai $87.18 \%$ kriteria sangat baik, soft skill kerjasama mencapai $86.14 \%$ kriteria sangat baik, soft skill disiplin mencapai $89.64 \%$ kriteria sangat baik, dan soft skill tanggung jawab sebesar $86.78 \%$ kriteria sangat baik. Pelaksanaan penanaman soft skills dalam pembelajaran produktif lebih banyak dilakukan dalam workshop berupa breafing, proses praktikum, kerapihan workshop, pemasangan tanda kesehatan dan keselamatan kerja dan lingkungan hidup, pelaksanaan tata tertib, pembuatan laporan praktikum dan proses evaluasi. (3) Soft skills siswa SMK di Kota Semarang sudah terserap dengan baik, hal ini bisa dilihat dari hasil persentase keterserapan soft skills secara generalisasi pada siswa SMK di Kota Semarang yaitu keterserapan untuk soft skill kemampuan berkomunikasi mencapai 83.37\% kriteria baik, soft skill kerjasama mencapai $86.16 \%$ kriteria sangat baik, soft skill 
disiplin mencapai $80.43 \%$ kriteria baik, dan soft skill tanggung jawab sebesar $82.07 \%$ kriteria baik.

\section{DAFTAR RUJUKAN}

Ali Mudlofir. 2011. Modul Pengembangan Soft Skills Guru Pendidikan Agama Islam. Jakarta: Direktorat Pendidikan Agama Islam Kementrian Agama RI.

Inpres No 6 Tahun 2014 tentang Peningkatan Daya Saing Nasional dalam Rangka Menghadapi Masyarakat Ekonomi Association Of Southeast Asian Nations.

Kimbrell, G \& Vineyard, B.S. (2006). Succeeding in the world of work Teacher wraparound edition. New York: Glencoe, McGraw Hill.

Organization for Economic Co - operation and Development. 2005. Definition and Selection of Key Competencies:Executive Summary. Paris: OECD.
Permendikbud Nomor 65 Tahun 2013 tentang Standar Proses Pendidikan Dasar dan Menengah.

Permendiknas Nomor 23 Tahun 2006 Menteri Pendidikan Nasional tentang Profil Lulusan SMK.

Sugiyono. 2014. Metode Penelitian Kuantitatif Kualitatif dan $R \& D$. Bandung: Alfabeta.

Surya Dharma dkk. 2013. Tantangan Guru SMK Abad 21. Jakarta: Direktorat Pembinaan Pendidik dan Tenaga Kependidikan Pendidikan Menengah Direktorat Jenderal Pendidikan Menengah Kementerian Pendidikan dan Kebudayaan.

Tim Pakar Yayasan Jati Diri Bangsa. 2011. Pendidikan Karakter di Sekolah. Jakarta: PT. Elex Media Komputindo.

Undang - Undang Nomor 13 Tahun 2003 tentang ketenagakerjaan.

Undang - Undang Nomor 20 Tahun 2003 tentang Sistem Pendidikan Nasional. 